\title{
Miłosza pobyty w równoległych (przekładowych) światach
}

\author{
[...] Świat \\ równoległy do naszego, nie nasz i trochę nasz.
}

Denise Levertov $^{\mathrm{I}}$

\section{Miłosz multiwalentny}

O tym, że twórczość Czesława Miłosza jest próbą uchwycenia pełni, ogarnięcia i oddania w słowie całości, a także intensywności ludzkiego doświadczenia, pisano już wielokrotnie. Wyraźnie wskazywał na to oczywiście sam Miłosz. Tęskniący do „formy bardziej pojemnej” ${ }^{2}$, pragnaccy obfitokształtne, widziane przez szypra galeonów „weneckie kurtyzany/ Opisać, jak w podwórzu witką drażnią pawia”, i równocześnie zamknąć ich doczesne szczątki „w słowie mocniejszym niż ostatni grzebień” ${ }^{3}$. Próbujący „[o]pisywać [...] ten, nie inny, kosz warzywa z położoną w poprzek lalką poru. / I pończochę na poręczy krzesła, suknię zmiętą tak, a nie inaczej" ". Marzący o tym, by zatrzymać „w niepowrotnej chwili” widzianą na międzywojennej adriatyckiej plaży północną pięknośćs. Z jednej strony ta cecha twórczości Miłosza łączy się z opisywaną przez Jana Błońskiego epifanią, kiedy to „w blasku jednej chwili” „poecie odsłania się «rzeczywiste», objawia «niewiadome», osiaga on - w widzeniu świata - «ostrość i przezroczystość»"6, a więc z „momentem wiecznym”, który, wedle koncepcji Aleksandra Fiuta, pomaga mu ominąć pułapki mimesis ${ }^{7}$. Na innych płaszczyznach natomiast wspomniana cecha poetyki autora Nieobjętej ziemi wiąże się z Miłoszowym „poszerzycielstwem” tradycji poetyckiej,

I D. Levertov, Pobyty w równolegtych światach, przeł. C. Miłosz, w: C. Miłosz, Przekłady poetyckie, red. M. Heydel, Kraków 2005, s. 583.

2 C. Miłosz, Ars poetica?, w: Wiersze wszystkie, Kraków 2011, s. 588.

3 C. Miłosz, Nie więcej, w: Wiersze wszystkie, s. 468.

4 C. Miłosz, Na trabach i na cytrze, w: Wiersze wszystkie, s. 569.

5 C. Miłosz, Sześć wykładów wierszem. Wykład II, w: Wiersze wszystkie, s. 965 .

${ }^{6}$ J. Błoński, Epifanie Miłosza, w: Poznawanie Miłosza. Studia i szkice o twórczości poety, red. J. Kwiatkowski, Kraków 1985, s. 208.

7 Zob. A. Fiut, Moment wieczny. Poezja Czestawa Miłosza, Kraków 1998. 
o którym pisał Jerzy Kwiatkowski ${ }^{8}$, lecz także z „układaniem świata z okruchów”, przejmujących detali: pamięci dawnych zdarzeń, nawarstwiających się pokładów zamierzchłej i współczesnej historii, widzialnej rzeczywistości oraz wiedzy wielu języków i literatur, na co zwróciła uwagę Helen Vendler ${ }^{9}$. Z tezą o Miłoszowej próbie całości współgra również idea księgi, postulowana przez Ryszarda Nycza ${ }^{\text {Io }}$.

Koncepcja „holistyczna” kulminowała, jak się zdaje, w pięknej i jakże pojemnej refleksji Błońskiego sformułowanej w tytule Miłosz jak świat ${ }^{\mathrm{II}}$. W ramach myślowego eksperymentu można się zastanawiać, czy formułę Seamusa Heaneya „Miłosz jako poeta światowy" ${ }^{\text {I2 }}$ uznamy za rewers tej pierwszej, jej konsekwencję, czy też jej uszczegółowienie. Sądzę jednak, że pewnym uszczegółowieniem koncepcji „Miłosz jak świat” mogłoby być czytanie twórczości Miłosza jako świata zwielokrotnionego. Zwielokrotnionego w przekładzie (i autoprzekładzie), który stanowi istotną, dopełniającą część jego dzieła. Zwielokrotnionego, gdyż zmiana języka i adresata pociąga za sobą nieuchronne przeobrażenia w projektowanym świecie przedstawionym, o czym pisał Edward Balcerzan, posługując się metaforą thumaczenia jako „wojny światów”: tego przedstawionego przez autora i tego "podstawionego", substytuowanego przez thumacza ${ }^{\text {I3 }}$.

Twórczość Miłosza postrzegana jako świat zwielokrotniony wiązałaby się jednak także ze zwielokrotnieniem przez przekład. Podejmowanie się tłumaczenia innych poetów - tak różnych, tak wielu - a więci ich poetyckich światów, naturalną koleją rzeczy zmusza przecież do podjęcia próby wykroczenia poza granice świata własnego idiomu i własnej wyobraźni. Przejścia do poetyckiego świata równoległego albo „możliwego”. Takiego, który byłby „nie nasz i trochę nasz”, jak pisała - ręką swego polskiego tłumacza, Czesława Miłosza - Denise Levertov w wierszu Pobyty w równoległych światach:

Żyjemy życiem ludzkich namiętności, okrucieństw, marzeń, wyobrażeń,

${ }^{8}$ Zob. J. Kwiatkowski, Miejsce Miłosza w poezji polskiej, w: Poznawanie Mitosza..., s.

9 Zob. H. Vendler, Zokruchów, światjużdoskonały, przeł. T. Kunz, w: Poznawanie Miłosza 2. Część pierwsza 1980-1998, red. A. Fiut, Kraków 2000, passim.

тo Zob. R. Nycz, Prywatna księga różności, „Teksty” 1981, nr 4-5.

II J. Błoński, Miłoszjak śwriat, Kraków 1998.

I2 S. Heaney, Czestaw Miłosz i poezja śrwiatowa, przeł. R. Gorczyńska, „Zeszyty Literackie” 1999, nr 2 (66), s. 49 i nast.

${ }_{3}$ Zob. E. Balcerzan, T'umaczeniejako „wojna światów”. W kręgu translatologii i komparatystyki, Poznań 2010. 
zbrodni i doskonalenia się $\mathrm{w}$ cnocie,

wewnątrz i obok świata, w którym nie ma

naszych zatrudnień $i$ wolnym

od niepokoju - choć na pewno

zależnym od naszych działań. Świat

równoległy do naszego, nie nasz i trochę nasz.

$[\ldots]$

Kiedy zapominamy o naszych obsesjach,

o zajmowaniu się sobą, bywa, że na krótko,

na godzinę, na minutę, jest (niemal) czyste

nasze innego świata przyjmowanie [...]

Nikt nie wie, gdzie naprawdę

byliśmy, z czym wracamy

do naszego kręgu (a musimy wrócić,

żeby spełnić nasze przeznaczenie) -

i jesteśmy już inni, choćby odrobinę ${ }^{I 4}$.

To prawda, nie jest to wiersz o sztuce thumaczenia, lecz o relacji człowieka $\mathrm{z}$ naturą, jednak pewne elementy tego stosunku „ja”, znikającego wobec percypowanej „inności”, wydają się szczególnie charakterystyczne w świetle wypowiedzi Miłosza o przekładzie. „[T]łumacząc, musimy zdobyć się na akt najzupełniejszej uwagi, $[. .$.$] wtedy nasza lektura jest taka, jak być po-$ winna”, proklamuje Miłosz w przedmowie do Mowy wiązanej ${ }^{i 5}$. „Najzupełniejsza uwaga” poświęcona Innemu zmusza nas, co banalnie oczywiste, do oderwania jej od siebie. Innego poetyckiego świata przyjmowanie, by sparafrazować myśl Levertov, wymaga zapomnienia o sobie. Kiedy jednak cofamy się o krok, żeby na sam akt tłumaczenia spojrzeć z dystansu, „ja” - przynajmniej „ja” Miłosza - wraca nieubłaganie. To dlatego wiersz Tłumaczac Annę Śrirszczyńska na wyspie Morza Karaibskiego opowiada tyleż o Annie Świrszczyńskiej, jej poezji i poezji tej tłumaczeniu, co o samym Miłoszu ${ }^{\mathrm{I} 6}$ :

Koło bananowców, na leżaku nad basenem

W którym Carol robi nago swoje pętle

Crawlem i klasycznym, przerywam jej

${ }^{14}$ D. Levertov, op.cit.

I5 Zob. C. Miłosz, Przekłady poetyckie, s. 7.

I6 Akcent na część „opowiada tyleż [...] o samym Miłoszu” położyłaby zapewne Agnieszka Kluba, autorka artykułu Interpretowanie kropki. O cyklu „Groteski” z tomu „Wiatr” Anny Świrszczyńskiej („Pamiętnik Literacki” 2005, z. 1). O Miłoszu jako tłumaczu Świrszczyńskiej pisała ostatnio także Joanna Brewińska w tekście T'tumacząc Annę Świrszczyńska, w: Czesław Miłosz i rewolucja, red. J. Madejski, Szczecin 2011. 
Pytając o synonim. I znów pogrążam się

$\mathrm{W}$ mruczącą polszczyznę, w rozpamiętywanie.

$\mathrm{Z}$ powodu nietrwałości umysłu i ciała, Z powodu twojej czułości dla naszego losu

Przywołuję ciebie i będziesz między ludźmi

Choć napisałaś w wierszu: „Nie ma mnie”. [...]

Kiedy zobaczyłem ciebie raz ostatni,

Zrozumiałem, dlaczego ciebie nie lubili,

Ani twojej poezji. Z tą twoją białą grzywą

Tylko jeździć na miotle, mieć diabła za kochanka,

A ty jeszcze obnosiłaś się

Z filozofią wielkiego palca u nogi,

Żeńskiej szpary, pulsu, grubego jelita ${ }^{\mathrm{I7}}$.

Miłosz, wychodząc od wiersza Świrszczyńskiej Podwoójny zachreyt („Że mnie nie ma. / I że czuję, jak bardzo/ mnie nie ma” ${ }^{18}$ ), który rozciąga na całą jej poezję, przypisuje tu Świrszczyńskiej cechę, której jego własnej twórczości przyznać chyba nie bylibyśmy skłonni (inna rzecz, czy bylibyśmy skłonni przypisać ją autorce tomu Jestem baba, a nawet Miłoszowego wyboru Mówie do swego ciała / Talking to My Body): Świrszczyńska, twierdzi Miłosz, potrafi sprawić, że w jej poezji „ja” staje się doskonale przezroczyste, znika:

Zaiste, wysławiając bycie:

rozkosz miłosnego dotyku, rozkosz biegania po plaży, wędrowania po górach, nawet grabienia siana,

Znikałaś, żeby trwać bezosobowo ${ }^{\mathrm{I} 9}$.

I tak jednak tym, co Miłosza w poezji Świrszczyńskiej interesuje najbardziej, jest jej niezwykle ekspresywna, kobieca somatyczność, dla niego - mężczyzny - niedostępna. W książce Jakiegoż to gościa mieliśmy, pełnej podziwu, wręcz czułości, Miłosz nazywa Świrszczyńską żartobliwie „Telimeną wyzwoloną”. „Znacznie jednak poważniej ją traktuję, niż mogłoby się wyda-

${ }_{7}$ C. Miłosz, Thumaczac Annę Świrszczyńska na wyspie Morza Karaibskiego, w: Wiersze wszystkie, s. 1070-1071.

I8 A. Świrszczyńska / A. Swir, Móweię do swego ciała / Talking to My Body, przeł. C. Miłosz, L. Nathan, Kraków 2002, s. 183.

I9 C. Miłosz, Tłumaczac Annę Świrszczyńską..., s. 1070. 
wać, sądząc po moich (męskich) przycinkach - pisze. - Bo pokażcie mi poetę, który by tak ekstatycznie pogrążał się w swoje ciało i poprzez jego radości tak utożsamiał się z Matką Ziemią" ${ }^{20}$. Nawet w swych najpiękniejszych, najbardziej przejmujących i najbardziej empatycznych wierszach o kobietach, do których arbitralnie zaliczyłabym Świty, Marie Magdalene $i$ mnie, Stare kobiety, perspektywa Miłosza pozostaje mimo wszystko perspektywą z zewnątrz. Może nie aż voyera, ale jednak obserwatora. W utworze Thumaczac Annę Świrszczyńska na wyspie Morza Karaibskiego autor Annaleny daje wyraz swojej fascynacji kobiecą somatycznością poezji Świrszczyńskiej, nad którą to somatycznością paradoksalnie nadbudowuje się metafizyka:

I ciało jest najbardziej tajemnicze,

Ponieważ tak śmiertelne, chce być czyste,

Uwolnione od duszy, która krzyczy: „Ja!”

Metafizyczna poetka Anna Świrszczyńska

Najlepiej czuła się stojąc na głowie ${ }^{21}$.

Tłumaczenie wierszy Świrszczyńskiej pozwala Miłoszowi przemówić - przynajmniej do pewnego stopnia - jej głosem. Do komplementarności, jaką poecie-tłumaczowi oferuje przekład, jeszcze powrócę, konsekwencją mojej koncepcji twórczości Miłosza jako świata zwielokrotnionego jest bowiem teza, że poeta, tłumacząc innych poetów, wzmaga swoją poetycką multiwalencję. Pomnaża twórcze możliwości. Sprawdza, czy nie mógłby być jednak kimś (poetycko) innym. Tłumaczenie poezji próbowałabym porównać do myślowego podążania porzuconą niegdyś ścieżką losu, co Miłosz czyni nierzadko, by wskazać choćby na obecny w jego późnej poezji motyw „gdyby wczesne kochanie spełniło się było" ${ }^{22}$. Motyw, który w tomiku Żywoty równoległe podejmuje Jacek Dehnel, autor wiersza Obywatel ziemski Czestaw M. objeżdża swój majątek w Szetejnach. Bohater liryczny Dehnela

Od ostróg po koniec szpicruty cały jest $\mathrm{z}$ baczenia, pola, łąki i stawy widzi jak z powietrza:

${ }^{\circ}$ C. Miłosz, Jakiegoż to gościa mieliśmy. O Annie Świrszczyńskiej, Kraków 2003, s. 98.

${ }_{21}$ C. Miłosz, Tłumaczac Annę Świrszczyńską..., s. 1071.

${ }_{22}$ Por. B. Toruńczyk, Miłosz: Na marginesie biografii, „Dwutygodnik” 2011, nr 64: http://www.dwutygodnik.com/artykul/2551 [dostęp: 21 listopada 2011]. 
rozrysowane na mapie granice majątków, gorzelnia, tartak, młyny.

\section{Zmierzcha}

ale on zmierzchu nie poznaje

i dopiero na skraju lasu

widzi, że słońce spieszniej niż zwykle

toczy się po niebie

nie tędy, nie tędy.

Przeciera oczy i zacina konia.

W oddali nad stołem lampa się kołysze,

Rubryki strat i zysków oświetlając gładko.

\section{Warszawa - Gabryelin, 1-2. V. 190323}

Zapewne i tak być mogło, gdyby autor $G d z i e$ weschodzi stońce $i$ kędy zapada nie poświęcił się gospodarstwu polskiej poezji.

Pośród poetyckich awatarów Miłosza, jego możliwych wcieleń, stworzonych tym razem przez niego samego, znaleźli się i powszechnie szanowany członek wileńskiego magistratu („Co niedziela zasiadałem w kolatorskiej ławce./ Nosiłem togę i złoty łańcuch, dar współobywateli. [...] Gdyby tak było naprawdę. Ale wywiało mnie/ Za morza i oceany. Żegnaj, utracony losie” ${ }^{24}$ ), i „Ciemno Wielmożny Profesor Milosz”. Najdalej w poszukiwaniu Miłoszowych awatarów posunął się chyba Heaney, pisząc, że Miłosz „może być pańszczyźnianym chłopem w drodze na sumę albo astronautą $\mathrm{w}$ stanie nieważkości, który stamtąd wychodzi”" ${ }^{25}$.

Pośród poetów przez Miłosza tłumaczonych, których ścieżką twórczości sam jednak nie podążył - chociaż wydaje się ona od jego własnej nie tak znów odległa, może równoległa właśnie znajdziemy między innymi Kazysa Borutę i Walta Whitmana, Matsuo Basho i Thomasa S. Eliota, Oskara Miłosza i Kabira, Robinsona Jeffersa i Konstandinosa Kawafisa, Annę Świrszczyńską i Denise Levertov, a także poetów murzyńskich, Koheleta i św. Jana z jego Apokalipsą.

23 J. Dehnel, V. Obywatel ziemski Czestaw M. objeżdża swój majątek w Szetejnach, w: Żywoty rówenoległe, Kraków 2005, s. 18.

${ }_{24}$ C. Miłosz, W mieście, w: Wiersze wszystkie, s. 1149.

25 S. Heaney, An Interview [with Randy Brandes], „Salmagundi” 1988, nr 80, s. 9-10, cyt. za: B. Carpenter, Recepcja poezji Czestawa Mitosza w Ameryce, przeł. T. Żukowski, w: Życie w przektadzie, red. H. Stephan, Kraków 2001, s. 45 . 


\section{Miłosz spowinowacony z wyboru i Miłosz komplementarny}

Miłoszowe próby transgresji poza granice świata własnego języka i własnej wyobraźni, do poetyckiego świata równoległego, który byłby zarazem „nie jego i trochę jego” (by raz jeszcze sparafrazować Levertov), odbywają się najczęściej dwojako: przez podobieństwo i przez dopełnienie. Ten podział komplikuje się w przypadku, kiedy Miłosz występuje jako tłumacz ambasador $^{26}$, reprezentant polskiej kultury, przekładający teksty najważniejsze i najbardziej dla poezji polskiej reprezentatywne ale chyba nie zostaje całkiem uchylony. Owszem, czym innym jest antologia Postwar Polish Poetry (1965), a nawet słynny wybór wierszy Zbigniewa Herberta, przełożony wspólnie z Peterem Dale'em Scottem (1968), a czym innym jego prywatna księga olśnień - Wypisy z ksiag użytecznych (1994) i A Book of Luminous Things (1996). Jednak nawet Miłosz ambasador nie thumaczy wbrew sobie, nie przekłada utworów całkowicie sprzecznych $\mathrm{z}$ własną poetyką. Co dość znamienne, $\mathrm{w}$ trzecim, rozszerzonym wydaniu Postwar Polish Poetry z 1983 r. pojawiają się raptem dwa, przedwojenne $\mathrm{w}$ dodatku, utwory Juliana Przybosia: Matka i Nad brzegiem, a w drugim wydaniu akademickiego podręcznika The History of Polish Literature (1983) Julian Tuwim jawi się amerykańskiemu czytelnikowi głównie jako autor przełożonego przez Lawrence'a Davisa i przytoczonego przez Miłosza wiersza Trawa oraz skromnego dwuwersu z Mieszkańców.

$\mathrm{Na}$ wielką księgę olśnień Miłosza, obejmującą całość jego translatorskiego dzieła, składają się utwory, które dobierał sobie na zasadzie szczególnego poetologicznego pokrewieństwa („,powinowactwa $\mathrm{z}$ wyboru”). „Na ogół szukałem u thumaczonych przeze mnie poetów pomocy $\mathrm{w}$ wypracowaniu własnego idiomu" - pisał o początkach swojej twórczości przekładowej ${ }^{27}$.

Są jednak w Miłoszowej księdze olśnień i utwory włączone tam na zasadzie przyległości czy - może lepiej: komplementarności. Świadectwa testowania samego siebie w intrygującym materiale, którego osobiście Miłosz nie byłby jednak skłonny stworzyć (a może, oddzielony barierą doświadczenia, nie

${ }^{26}$ Koncepcję „tłumacza-ambasadora”, który przekłada literacki kanon, przeciwstawionego „tłumaczowi-legislatorowi”, który przekładając dane teksty, chce za ich pomocą zmienić ksztalt swojej literatury narodowej, zapożyczam z pracy Jerzego Jarniewicza Tłumaczjako twórca kanonu, w: Przektad - język kultura, red. R. Lewicki, Lublin 2002, passim.

${ }_{27}$ C. Miłosz, Gorliwość thumacza, w: Ogród nauk, Lublin 1991, s. 175. 
potrafiłby?) - to chyba właśnie casus fascynacji poezją Świrszczyńskiej.

I jedne - pokrewne, i drugie - komplementarne należałyby do utworów, na które Miłosz miał apetyt. Impuls popychający go do przekładu próbował niegdyś zobrazować, przedstawiając „uczucia myszy, siedzącej w środku olbrzymiego sera. Miniona cywilizacja ludzkości jest takim olbrzymim, smakowitym serem. Spożywanie jednak tego sera samotnie jest zajęciem zbyt egoistycznym, aby dawało pełnię zadowolenia. Mysz pragnie towarzystwa, jeżeli nawet nie muzyki, która by przygrywała uczcie" ${ }^{28}$.

Lecz są w dorobku translatorskim Miłosza i takie teksty, które przekładał na zamówienie, a mimo to zdają się rozbrzmiewać echem w jego późniejszej twórczości. W okolicznościach towarzyszących tłumaczeniu Sailing to Byzantium Williama Butlera Yeatsa w końcu lat 50. nie było żadnych olśnień, niczego czarodziejskiego, a jednak idea szeroko rozumianego „Bizancjum”, „nienaruszonego trwania dzieł ludzkiego umysłu i ręki” ${ }^{29}$, znajduje w późniejszej twórczości Miłosza znaczny rezonans. Ech Odjazdu do Bizancjum nasłuchuję i w deklaracji akcesu do grona „[k] upców i rzemieślników Cesarstwa Japonii/ Układających wiersze o kwitnieniu wiśni, / O chryzantemach i pełni księżyca" ${ }^{\circ}$, i w namowach adresowanych do pięknej cudzoziemki na adriatyckiej plaży: „W rzeźby hieratyczne/ Schroń się, w mozaiki katedr, złotobarwne zorze" ${ }^{\text {I }}$, a nawet w przypuszczeniu z Dalszych okolic:

8. Mawet, mors, mirtis, thanatos, smrt.

Tak oto kończy się stan posiadania,

Wszystko, na co zwykłem był mówić: moje.

Tak oto kończy się stan umysłu.

Chłód absolutny. Jak wezmę ten próg?

Szukam, co jest najmocniejszym przeciwieństwem smrt.

I myślę, że muzyka. Muzyka baroku² ${ }^{2}$.

${ }^{28}$ C. Miłosz, O przekładach, w: Kontynenty, Kraków 1999, cyt. za: E. Balcerzan, E. Rajewska, Pisarze polscy o sztuce przektadu 1440-2005. Antologia, Poznań 2007, s. 199.

29 C. Miłosz, Wstę, w: W.B. Yeats, Odjazd do Bizancjum. Wieża / Sailingto Byzantium. The Tower, przeł. C. Miłosz, Kraków 2004, s. 13.

$3^{\circ}$ C. Miłosz, Nie więcej, w: Wiersze wszystkie, s. 468.

${ }^{3}$ C. Miłosz, Sześć wykładów wierszem. Wykład II, w: Wiersze wszystkie, s. 965.

$3^{2}$ C. Miłosz, Dalsze okolice, w: Wiersze wszystkie, s. 1000-1001. 


\section{Miłosz jako tłumacz}

W Przypisiepo latach do swoich Kontynentów Miłosz przedstawia się jako ten, kto w dziejach literatury tłumaczonej na język polski niemalże samodzielnie przesunął środek ciężkości z literatury francuskojęzycznej na literaturę anglojęzyczną. W Abecadle jako twórca szkoły tłumaczeniowej, „miłoszystów”, do których zalicza Richarda Louriego, Louisa Iribarne'a, Katherine Leach, a także Bogdanę Carpenter ${ }^{33}$.

„Na Uniwersytecie w Berkeley prowadziłem seminarium przekładów poezji, wykorzystując to, czego się nauczyłem w naszym gimnazjum w Wilnie na lekcjach Adolfa Rożka. Była to metoda demokratyczna thumaczenia zespołowego" 34 - pisze. W pamięci jednego z kolegów z klasy gimnazjalnej Miłosza zajęcia $\mathrm{z}$ Rożkiem zapisały się $\mathrm{w}$ sposób, który może budzić poważne zastrzeżenia współczesnych krytyków przekładu, jeśli był to główny element zalecanej przez niego strategii thumaczeniowej: „W tłumaczeniu tekstów [Adolf Rożek] dbał o to, aby przekład nie był prostacki, lecz bardziej uroczysty i w ładnym stylu, a więc np. nie «wielka sława», lecz «szczytna», nie «zginął w bitwie», lecz «oddał życie» lub «poniósł śmierć»" ${ }^{5}$. Szczęśliwie przekłady Miłosza i „miłoszystów” nie grzeszą upoetycznianiem języka za wszelką cenę, wzbudzają jednak pewne kontrowersje.

Tego typu wątpliwości nie zgłasza Heaney, który przyznaje:

Znam poezję Miłosza tylko w przekładzie, lecz przecież, czytając te wiersze po angielsku, łatwo zapomina się o problemie językowym. Czytelnik poddaje się niepowtarzalnemu stylowi, poezji niosącej doświadczenie o niezwykłej gęstości, przeżyte i rozświetlone przez umysł, który uczynił je symbolicznym. Nie chodzi tu jedynie o zaufanie do słuchu i dokładności poetów, którzy dokonali przekładu - choć ich wkład był nieodzowny i twórczy. Chodzi o coś więcej niż to, że nie sposób nie wyczuć znaczenia ludzkiej osobowości, zawartości prozatorskiej i przekazu muzycznego, które są niewątpliwie obecne w oryginale, poza naszym zasięgiem językowym. Poezja ta jest w całości nadzwyczaj zrozumiała i nie do zlekceważenia ${ }^{36}$.

33 Zob. C. Miłosz, Lourie, Richard i Jody, w: Abecadło Mitosza, Kraków 1997, s. 161.

34 C. Miłosz, Angielski, język, w: Abecadło Miłosza, s. 37.

35 Wspomnienie Tadeusza Kasprzyckiego podaję za książką Andrzeja Franaszka, Miłosz. Biografia, Kraków 2011, s. 70-71.

${ }^{6} 6$ S. Heaney, Śmierć starego króla, przeł. A. Skucińska, „Tygodnik Powszechny" 2004, nr 35. Także: www.milosz.pl [dostęp: 21 listopada 2011]. 
Twórczość Miłosza wyłącznie w tłumaczeniu zna także Vendler:

Podobnie jak większość obcokrajowców piszących o poezji Miłosza, nie znam języka polskiego. Wiersze zostały jednak wyjątkowo dobrze przełożone, częściowo przez samego autora, częściowo przez tłumaczy, z którymi współpracował37.

Vendler, pisząc, że Miłosz stosuje konstrukcje wielogłosowe, łączy styl „niski” z ,wysokim”, wirtuozowsko zestawia ze sobą słowa, które nigdy wcześniej nie stały obok siebie, powołuje się na recenzję Stanisława Barańczaka, nie wyczytuje tego z samych przekładów.

Czytając Miłosza, pozbawieni [...] jesteśmy, jako cudzoziemcy, uczucia owej najczystszej rozkoszy, jaką daje obcowanie z nowym upostaciowaniem języka; uczucia, którego doświadczają osoby znające ojczystą mowę poety. Nie usłyszymy też właściwego dla tej poezji falowania linii intonacyjnej ani brzmienia kadencji. Jaką zatem korzyść możemy odnieść z czytania wierszy Miłosza, jeśli niedostępna jest nam eufonia jego ojczystego języka i jeśli omija nas wiele zaskakujących oraz (jak nas zapewniają) wyjątkowo urzekających efektów jego dykcji poetyckiej, która za pomocą jednego słowa wywołuje z przeszłości dawno zapomniane lub nie dostrzegane obszary polskiej tradycji i stawia je na równi z teraźniejszością? ${ }^{8}$

- pyta Vendler. I odpowiada:

Znajdujemy $\mathrm{w}$ nich przede wszystkim rudymentarną autobiografię 39 .

Jakże mało. Autobiografia to przecież znacznie mniej niż Miłoszowe „nic, najwyżej piękno”. Może dlatego Josif Brodski zdecydował się podjąć naukę języka polskiego, żeby móc czytać $\mathrm{w}$ oryginale tę ,najbardziej niezwykłą” poezję wieku $\mathrm{XX}^{40}$.

$\mathrm{Na}$ tym tle wyraźnie odcina się głos Jeremy'ego Noel-Toda, który na pytanie, w jaki sposób przekłady wierszy Miłosza istnieją w literaturze angielskiej, bez pardonu odpowiada, że wcale nie $\mathrm{w}$ doskonały. Język tych tłumaczeń wydaje mu się co naj-

37 H. Vendler, Z okruchów, świat już doskonały, s. 342.

$3^{8}$ Ibidem.

39 Ibidem, s. 343.

$4^{\circ}$ Jak zaświadcza Clare Cavanagh w The Americanization of Czeslaw Milosz („Literary Imagination” 2004, nr 6, s. 334). 
mniej dziwny, hybrydyczny, „(wysoka angielszczyzna upstrzona tu i ówdzie amerykanizmami)”. „Można się zastanawiać, czy udział Miłosza nie zagłuszał czasem w jego współpracownikach rozeznania co do możliwości ich własnego, ojczystego języka" ${ }^{1 \mathrm{I}}$ - stwierdza krytyk.

Pomimo monumentalnej oprawy tomu, Collected Poems jest prowizorycznym zbiorem tłumaczeń różnej jakości, dosłownych, wiernych i wolnych. Takie nagromadzenie odcisków palców na narzędziu zbrodni w sposób nieunikniony rodzi dalsze niepokojące pytania czy to samo charakterystyczne słowo pojawiające się w różnych utworach odpowiada podobnemu powtórzeniu w oryginale? ${ }^{42}$

Angielski czytelnik, który nie włada polszczyzną - odbiorca, do którego ta 43 antologia wierszy Miłosza jest skierowana - musi przyznać, że zamieszczone w niej utwory mimo wszystko przynależą do innego, nie w pełni odkrytego świata ${ }^{44}$.

Jednocześnie wkład Miłosza w dzieje przekładu w Polsce, a także popularyzację polskiej poezji w krajach anglojęzycznych kontrowersji nie budzi. Nie ulega kwestii, że to jego antologia Postwar Polish Poetry stworzyła miejsce dla współczesnej polskiej poezji na scenie amerykańskiej, pisze Mira Rosenthal ${ }^{45}$. W Stanach Zjednoczonych Miłosz jest uważany za tego, który jako pierwszy zwrócił uwagę anglojęzycznej publiczności na polską poezję, poświadcza Cavanagh ${ }^{46}$.

Dyskusyjne natomiast mogą się wydawać jego poglądy na sztukę thumaczenia. Miłosz - który w roku 1958 uważał, że przekładu z drugiej ręki nie należy się wstydzić, „trzeba tylko, żeby tłumacz znał składnię języka, w którym napisany jest oryginał”, i stawiał pytanie retoryczne: „Ilu pisarzy w Polsce zna hindustani? Ilu zna gaelicki? Ilu zna baskijski? Ilu wreszcie zna chiński? Czy to znaczy, że nie należy tych literatur tłumaczyć?” 47 - zaznacza i w roku 1999, że „upływ czasu nie zmie-

$4^{\mathrm{I}}$ J. Noel-Tod, Dla was Miłosz, dla mnie Meewosh, przeł. E. Rajewska, „Literatura na Świecie” 2003, nr 1-2, s. 420.

$4^{2}$ Ibidem, s. 421.

43 Chodzi o zbiór: C. Miłosz, New and Collected Poems 1931-2001, Allen Lane 2001.

44 J. Noel-Tod, op.cit., s. 428.

45 M. Rosenthal, Revising Anna Świrszczyniska. The Shifting Stance of Czestaw Miłosz's English Translations, "Canadian Slavonic Papers” 2010, t. 52, z. 1/2, s. 62 .

${ }_{46}$ C. Cavanagh, op.cit., s. 346.

47 C. Miłosz, O przektadach, s. 202-203. 
nił [j] ego przychylnego stanowiska wobec świadomego przyjęcia rozwiązań niedoskonałych” i że "nie ma w tym względzie wielu skrupułów" ${ }^{8}$.

Wiersze języka angielskiego i francuskiego thumaczyłem z oryginału, z innymi było rozmaicie, a już na pewno nie próbowałem sprawdzać, jak brzmią chińskie i japońskie oryginały. Zresztą i angielskie „wariacje na temat” mają swoją historię, bo ich autorzy najczęściej filologami nie są i korzystają z pomocy swoich azjatyckich przyjaciół czy też wersji francuskich. [...] Moje ambicje nie sięgają dalej niż dostarczenie wierszy, które sprawdzają się w języku polskim ${ }^{49}$.

Intrygująco przedstawiają się także Miłoszowe próby ustalania kanonu literackiego z perspektywy władzy i za pomoca przekładu: szczególne sprzężenie zwrotne, które usiłował wytworzyć Miłosz, by wzmocnić poetycką pozycję Świrszczyńskiej, promując ją (oraz thumaczony przez siebie wybór jej poezji) jednocześnie w Stanach Zjednoczonych i Polsce, zbadała i opisała Rosenthal $5^{\circ}$.

Innego poetyckiego świata przyjmowanie wymaga zapomnienia o sobie - napisałam. Wymaga zapomnienia czy je umożliwia? Może pozwala na chwilę unieważnić podział na „mojość” i „inność”, w tym także, co pewnie byłoby bliższe parafrazowanej myśli Levertov, na przykład na „człowieczość” i „psiość”, z jej „esencją, niepoznaną, psiości”, w zetknięciu z którą „,człowieczość nasza [...] wyraźnieje” ${ }^{1}$. Unieważnić, aby rozpoznać się w Innym. Zapomnieć o sobie, żeby paradoksalnie do siebie powrócić. Miłoszowi, który, doznawszy lekturowych i tłumaczeniowych olśnień, układa swoje prywatne księgi różności: Ogród nauk, Mowę wiąana, Wypisy z ksiag użytecznych, Abecadło Miłosza, Spiżarnię literacka, zdaje się przyświecać ta sama, ,jedna mimo wszystko myśl, trudna, starająca się uchwycić siebie w różnych postaciach i słowami różnych autorów" ${ }^{2}$.

\footnotetext{
$4^{8}$ C. Miłosz, Wypisyz ksiag użytecznych, Kraków 2000, s. 6, 16.

9 Ibidem, s. 16.

5० M. Rosenthal, op.cit.

${ }^{5}$ C. Miłosz, Śrwiadomość, w: Wiersze wszystkie, s. 838-839.

$5^{2}$ C. Miłosz, Ogród nauk, s. 6.
} 
Tak, to jest pełnia, ta, której szukałem. Znaleziona nie w księgach filozofii, nie w ławkach kościelnych, nie w biczowaniu siebie dyscypliną. Po dniu przeróżnych działań w półśnie o świcie czuć w sobie jedność z ludźmi przypominanymi, wbrew myśli o własnej oddzielonej od innych osobie 53 .

\section{EWA RAJEWSKA}

\section{Miłosz's Sojourns in Parallel (Translation) Universes}

The well known interpretation of Miłosz's work as an attempt to capture fulness, has been most fully formulated by Jan Błoński's "Miłosz jak świat" ["Miłosz like a World"]. The author of the article provides a more detailed version of the interpretation, presenting Miłosz's work as a multiplied universe: in translation and in self-translation. Miłosz's universe has been multiplied through translation: undertaking translation of so many and so various poets, Miłosz, by extension, translated their poetic worlds. In doing so, he had to go beyond the borders of the world of his own idiom and imagination. Miłosz's attempts at transgression beyond the borders of his own language and imagination, and into a poetic "parallel universe", are conducted, according to the present author, in two ways: through similarity and through completion. Miłosz translates works which he which he selected on the principle of an exceptional poetic kinship (for example in his Excerpts from Useful Books). Other translations were an opportunity to test himself on an intriguing poetic material, which he himself would not be willing to create (for example in poetry by Anna Świrszczyńska).

Keywords: Czesław Miłosz, Anna Świrszczyńska, translation, authorial poetics, poetics of translation.

Ewa Rajewska - doktor, adiunkt w Instytucie Filologii Polskiej UAM; literaturoznawczyni, translatolożka i tłumaczka. Autorka książek o twórczości oryginalnej i przekładowej Stanisława Barańczaka: Stanistaw Barańczak poeta $i$ thumacz (2007) oraz o polskich przekładach Alice's Adventures in Wonderland Lewisa Carrolla: Dwie wiktoriańskie chwile w Troi, trzy strategie translatorskie (2004); współredaktorka przygotowanej z Edwardem Balcerzanem antologii Pisarze polscy o sztuce przekładu 1440-2005 (2007). Kierowniczka specjalności przekładowej na studiach polonistycznych drugiego stopnia (www.przekladowa.amu.edu.pl).

e-mail: rajewska@amu.edu.pl

53 C. Miłosz, *** Czy mogłem się spodziewać..., w: Wiersze wszystkie, s. 900. 